\title{
スポンジケーキの物性に及ぼすトランスグルタミナーゼの影響
}

\author{
山㟝勝利 ${ }^{\S}$, 鳴戸 康*, 上田要一* \\ (株)あじかん 研究開発センター（元 味の素(株）商品開発センター） \\ *味の素(株) 商品開発センター
}

\section{Effects of Microbial Transglutaminase on Mechanical Properties of Sponge Cake}

\author{
Katsutoshi Yamazaki ${ }^{\S}$, Yasushi Naruto* and Youichi Ueda* \\ Ahjikan CO., LTD. Research \& Development Laboratories, 5-5-24, syoukoucenter westsuide, \\ Hirosima city, Hirosima 733-0833 \\ *Ajinomoto CO., LTD. Research \& Development Laboratories, 1-1, Suzuki-cho, Kawasaki-ku, \\ Kawasaki, Kanagawa 210-8681
}

\begin{abstract}
Effects of transglutaminase derived from microorganisms (MTG) on mechanical properties of sponge cake were evaluated. The specific volume of sponge cake increased by the addition of MTG at 0.5-5.6 u/gp. When MTG was used with other quality-improving agents, its effect was enhanced by the concomitant use of an emulsifier, a viscosity-increasing polysaccharide, and a wheat degradation product. The specific volume was increased to about 1.2 times by the use of $1.4 \mathrm{u}$ MTG and $0.2 \%$ emulsifier compared with MTG alone. By the addition of MTG, sponge cake with a better appearance having no depression or creases on the top surface was obtained, and the optimal dosage of MTG was $0.5-1.4 \mathrm{u} / \mathrm{gp}$. When MTG was added at more than $2.8 \mathrm{u} / \mathrm{gp}$, the surface tended to be slightly hardened, but a crumb with a good shape-retaining property was obtained by the simultaneous addition of an emulsifier and a viscosity-increasing polysaccharide, air bubbles were distributed adequately, and a moist and soft feeling on eating was obtained. On testing of mechanical properties by the breaking test, the breaking distance as well as the breaking strength increased by the addition of $1.4 \mathrm{u} / \mathrm{gp}$ MTG compared with no MTG, suggesting improvements in both elasticity and softness. On SDS-PAGE, a decrease in low-molecular-weight gliadin was noted, indicating the usefulness of MTG for improving the quality of sponge cake and its primary substrate protein.
\end{abstract}

(Received Oct. 4, 2004 ; Accepted Mar. 2, 2005)

近年, 嗜好の多様化により調理パン, フランスパンや ケーキ類の需要が伸びており, 特に, 手作り志向から, オープンベーカリーシステムが好まれている。そして，料 理の手間が省けて家庭や職場に持ちかえって食べられる調 理済みパンや小麦粉ベースにすべての素材が配合された 「スポンジケーキの素」などの開発も進んでいる.

スポンジケーキは卵, 砂糖, 小麦粉を主原料に, 卵の起 泡性とその安定性を利用したスポンジ状の組織を形成する ケーキ類の総称である. スポンジケーキの品質に影響する 小麦粉の種類 ${ }^{1)}$ や副原料の砂糖 ${ }^{2) 3}$ やバターなどの配合

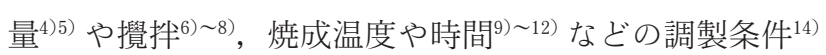
については既に多くの研究 ${ }^{19) 20)}$ がなされている. 主原料の 小麦粉についてみると, 武田ら ${ }^{13)}$ は小麦粉を適正条件下で 長期保存（エージング）することによってスポンジケーキ の膨化がよくなるとしている，また，藤井ら ${ }^{15)}$ は小麦デン

=733-0833 広島市西区商工センター 5丁目 5-24

* =210-8681 川崎市川崎区鈴木町 1-1

$\S$ 連絡先 (Corresponding author), k-yamazaki@ahjikan.co.jp
プンで調製したスポンジケーキの生地特性を明かにしてい る. そして, 藤井ら ${ }^{16)}$ はスポンジケーキに必要な品質要件 として，第一に十分に膨化していること，第二には，外観 は凹みや㱀がなく, 均質で焼き色が濃く, 固くてしっかり したクラストが形成されていること，第三には，しっとり して，ふんわりした柔らかいテクスチャーなどの点を満た されることを挙げている.

現在, タンパク質架橋重合化機能を持つトランスグルタ ミナーゼ (以下, MTG と略す) ${ }^{17)}$ はタンパク質中の Gln 残 基と Lys 残基間の結合を触媒する酵素であり, 原料小麦 粉の小麦タンパク質であるグルテンに作用させて, タンパ ク質分子内抢よび分子間に $\varepsilon-(\gamma-G l u) L y s$ 架橋結合（以下， G-L 結合と略す）を形成する.

このようなことから，本報では，スポンジケーキの基本 原料である卵: 小麦粉: 砂糖: バターの一般的配合比率を 参考に 190 : 100: 100：40 を基に, MTGの小麦タンパク 質への架橋重合反応によりグルテンのネットワーク構造が 強化されると予想された。 そこで, スポンジケーキ生地中 
に及ぼすバッターの特性や焼成過程に表れる嵩比容などを 評価し, ふっくらとして柔らかい食感への効果や, 凹みや 媰皮のない内相の形成が MTG による小麦タンパク質の改質 によるものかを検討し， スポンジケーキ調製における加工 特性に及ぼす MTGの影響を明かにすることを目的に実験 を行った。

\section{実 験 方 法}

\section{1. 試 料}

原料の卵は市販のものを卵黄と卵白量の比を一定量にあ わせて使用, 砂糖は新日本製糖(株) の「上白糖」, バ夕ー はよつば乳業(株)の「無塩バター」(水分 $14.5 \%, \exists ウ$ 素価 31.5, 酸化 1.04). 小麦粉は日清製粉(株) の「バイオレッ 卜」(タンパク質 $7.10 \%$, 灰分 $0.33 \%$ ), 乳化剤は三菱化成 食品(株) の「リョートーシュガーエステル S-990」（HLB $=16$ ), 増粘多糖類は大日本製薬(株) の「グアーガム」を 用いた. MTG は味の素(株) の「アクティバ」TG-M コシ キープ (MTG 酵素力価は $20 \mathrm{unit} / \mathrm{g}$ ) で DMV ジャパン （株）製のタンパク部分分解物「グルタミンペプチド」(平 均分子量約 3000）を $2 \%$ 配合したもの. 小麦タンパク分解 物は片山化学工業(株) の「グルパールNo. 572C」を用い た。

\section{2. スポンジケーキの調製}

スポンジケーキ（以下，ヶーキと略称する）の調製法に は, 大別して共立て法と別立て法がある。本報では, 生地 バッターの攪拌や焼成などの調製条件の影響を受けないよ うに山上ら ${ }^{14)}$ の報告から Fig. 1 のフローに従って室温 $20^{\circ} \mathrm{C}$ のテストベーキング室にて共立て法で行った. 混練機 は (株)エフ・エム・アイ製の縦型ミキサー「KitchenAid KSM-5 型」にて, プランジャーにワイヤー・ホイップを用 いて行った。 バッター調製ではバッター見かけ比重が重要 な要因であるので， 0.212〜0.250 にそろえた。すなわち， $20^{\circ} \mathrm{C}$ の全卵 $380 \mathrm{~g}$ （卵黄 $152 \mathrm{~g}$ と卵白 $228 \mathrm{~g}$ ）をステンレ ス・スチール・ボウルに計量し, 上白糖 $200 \mathrm{~g}$ を半量づつ 2 回に分けて投入して，回転数 $200 \mathrm{rpm}$ で 10 分間攪拌を 行った. 山上 ${ }^{14)}$ らは生地バッターの攪䢁の過不足がケーキ 内相の状態および焼成後の比容積に影響するとしているの で，小麦粉 $200 \mathrm{~g}$ に MTG を 0, 0.5，1.4，2.8，5.6，および $14 \mathrm{u} / \mathrm{g}$ protein 量を各々混合して加えた後, KitchenAid の混練速度は $80 \mathrm{rpm}$ で 1 分間とした。次に， $40^{\circ} \mathrm{C}$ に溶か したバター $80 \mathrm{~g}$ を加えて川染ら ${ }^{6)}$ のデータからも安定す る $80 \mathrm{rpm}$ で $50 \mathrm{sec}$ 攪挥を行い, 焼成前のバッ夕一比重を 25〜 $28^{\circ} \mathrm{C}$ で $0.430 \sim 0.470$ に設定した.

このスポンジケーキバッターをケーキ型No.「B-104」直 径 $130 \mathrm{~mm} \times$ 高さ $40 \mathrm{~mm}$ のケーキ用型枠にグラシン紙を ケーキ枠および底辺に敷き詰めてセットし， スポンジケー キバッター $140 \mathrm{~g}$ を気泡を壊さないように静かに加えた。

各 5 つのケーキ型に分注した後, 藤沢製作所(株)の焼成
機「プリンスオーブン I 3 段デッキオーブン」にて $180^{\circ} \mathrm{C}$ で 15 分間焼成した。

\section{3. バッター及びスポンジケーキの諸測定}

(1) バッターの比重

調製直後のバッターを $40 \mathrm{ml}$ 容の計量カップに隙間なく 詰め, 重量を測定して, 同容器中の水の重さで除して比重 を測定した。

（2）ケーキの比容積の測定

焼成後, オーブンより取りだし 40 分放冷し, 室温に戻っ てから比容積を（株）アステックス社製の3DLaser Scanner 式 3 次元イメージ計測計「SELNAC-VM150 型」にて容積, 高さ, 外径 $(1,2)$ を測定し, 比容積は容積 $\mathrm{cm}^{3}$ /重量で表 し試料 5 回の平均值で示した.

(3) ケーキの物性

ケーキの物性測定は, 焼成したケーキの上面を $10 \mathrm{~mm}$ カットし縦, 横, 高さが $30 \times 30 \times 30 \mathrm{~mm}$ の正方型にて, 不 動工業(株)のレオメータ「2202 型」により破断試験を行っ た. 検出器 $2 \mathrm{~kg}$, レンジ $200 \mathrm{~g}$, テスト速度 : $6 \mathrm{~cm} / \mathrm{min}$, プ ランジャー : $8 \mathrm{~mm} \phi$ 平板プランジャーを用いて 2 試料に つき各 5 個の計 10 ケーキ片を測定して平均值を求めた。

(4) ケーキの官能評価

ケーキの官能評価は外観の色調, 内層の柔らかさ, しっ とり感, 保形性, 総合評価の 5 項目を評価した。無添加品 を 5 点としてパネラー 10 名による 10 段階評点法で評価し た。

(5) ケーキの SDS-PAGE 測定

焼成したケーキの MTG による小麦タンパク質の作用性 をみるために, Laemmli の方法 ${ }^{18)}$ に従って SDS-PAGE を 測定した。ケーキ各 $1 \mathrm{~g}$ を $50 \mathrm{ml}$ に溶解し, $100 \mu \mathrm{l}$ に対して 4\%の SDS を含む $0.01 \mathrm{M}$ トリス塩酸緩衝液（pH 6.8）を $100 \mu 1$ 溶解し， $5 \mu 1$ をそれぞれ電気泳動に供した。 ポリア クリルアミドの濃度は $10 \%$ とし染色はクマシーブリリア ントブルーR-250を用いた. デンシトメトリーは島津製作 所(株) 製の二波長フライングスポットスキャナー「CS9000P/N206-13300 型」を用いて波長 $640 \mathrm{~nm}$ で測定した.

(6) ケーキの外観および断面図測定

外観は MINOLTA 社「DIMAGE20 型」デジカメで撮影 し，断面はカットした後にリコーのコピー機にて複写した.

(7) ケーキの水分

焼成後のケーキをケット（株）の「Kett 水分計 FD600-2 型」にて $130^{\circ} \mathrm{C}, 20$ 分の条件で水分を測定した。

\section{実験結果および考察}

\section{1. バッター比重と比容積}

ケーキの調製は Fig. 1 に示したバッター生地配合及び 調製条件で行った。全卵の第一段階の攪拌では，各調製段 階の比重は $25 \sim 28^{\circ} \mathrm{C}$ で 0.212〜0.250 とほぼ一定となり, 卵 白の起泡性による安定したバッターを形成した。 小麦粉を 


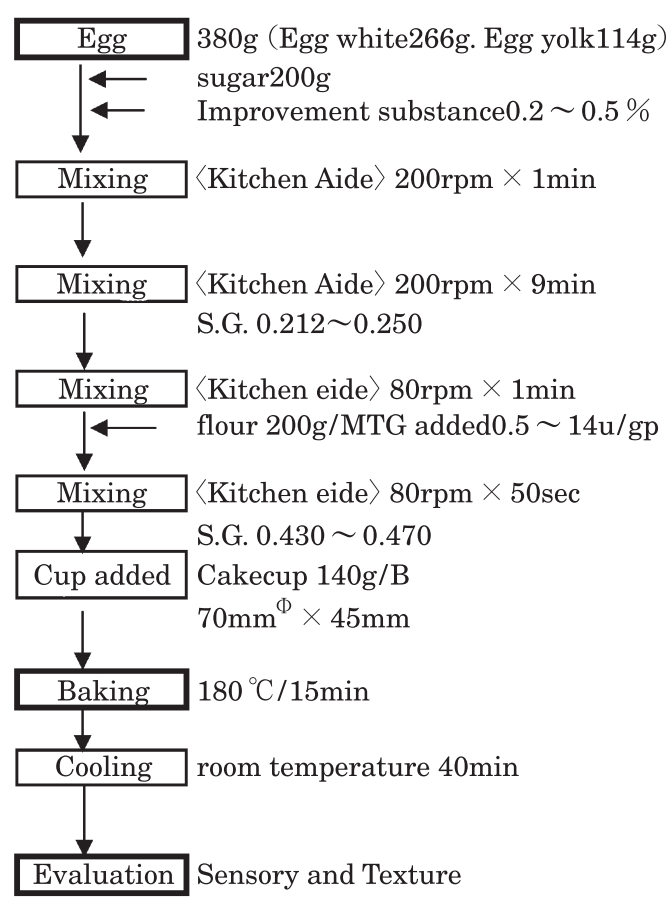

Fig. 1 Preparation of sponge cake

加えた第 2 段階では $0.430 〜 0.470$ に設定した. 川染・山 野 $^{2)}$ 井川ら ${ }^{12)}$ はバッターの比重を 0.430 が適切としてお り， 0.470 以上ではバッター比重とケーキ比容積の間には 負の相関があるとした適切な範囲内であった。本条件で調 製したこのデータから Fig. 1 に示すフローの条件にて調 製した結果，ケーキの比容積は Fig. 2 に示すように MTG の添加量によって無添加に対して向上する傾向を示した. バッターの泡立て温度は Mizukoshi ${ }^{3)}$ 越智8) らの標準とす る $28^{\circ} \mathrm{C}$ で行い, 越智らの泡立て温度からも, 無添加に対し て安定した比容積が得られ, MTGの添加量の増加に従っ て比容積が向上した. MTG $5.6 \mathrm{u} / \mathrm{gp}$ 量において最も高い 嵩比容が得られ, MTGによる小麦タンパク質の架橋重合 化の影響であることが示唆された。

MTG 添加量の最も高い $14 \mathrm{u} / \mathrm{gp}$ では, 比容積の減少が みられ, このことは, 逆に, MTG 添加量の増加により架橋 重合化がさらに進み, 小麦タンパク質の網目構造の強化に よって膨化が抑制されたためと考えられる。

\section{MTG と改質材併用による比容積}

MTG 単独に対して他の改質材として乳化剂, 増粘多糖 類および小麦タンパク分解物の単独および併用における効 果をみた. 経済性の点から MTG 添加量は $0.5 \mathrm{u} / \mathrm{gp}$ 量に固 定して他の改質材 $0.2 \%$ および $0.5 \%$ との併用を試みた結 果, 乳化剂との併用では, Fig. 3 のように, MTG 単独の場 合よりも MTG $0.5 \mathrm{u} / \mathrm{gp}$ と乳化剂 $0.2 \%$ 併用では, 増粘多 糖類, 小麦夕ンパク質分解物, 乳化剂の順に高い比容積の 発現がみられ, 改質材は $0.5 \%$ 添加で乳化剂, 増粘多糖類, 小麦タンパク分解物の順に効果が得られた。 さらに，図に

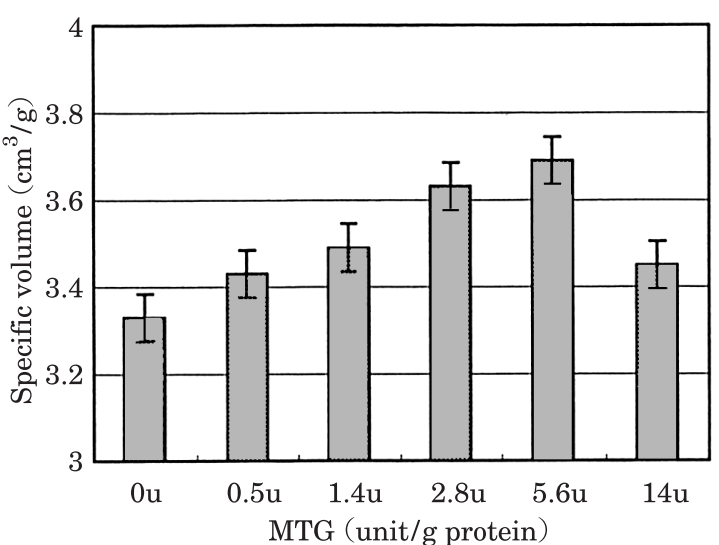

Fig. 2 The effect of MTG content at level of 0, 0.5, 1.4, $2.8,5.6$ and $14 \mathrm{u} / \mathrm{g}$ protein on specific volume of sponge cake

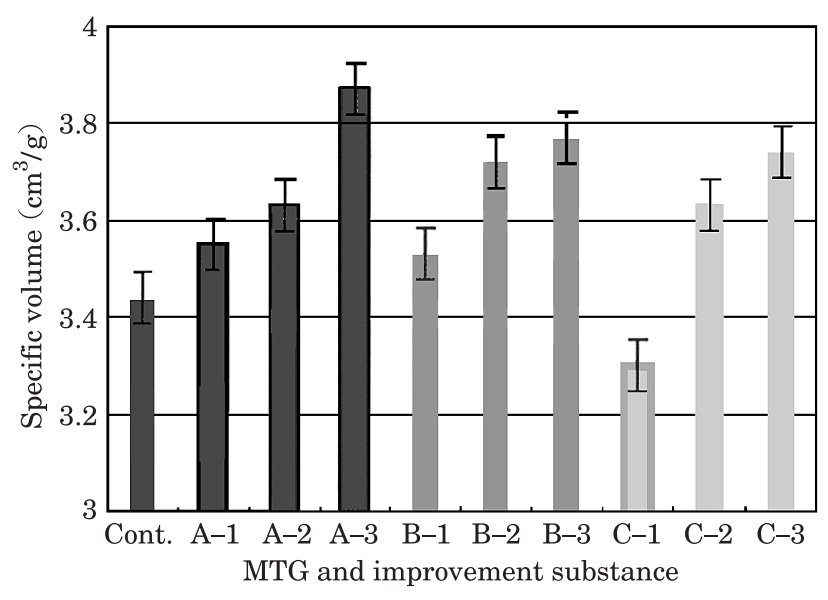

Fig. 3 Effect of food additives on specific volume Cont, MTG $0.5 \mathrm{u} / \mathrm{gp}$;

A-1, emulsifying agent only $0.2 \%$;

A-2, MTG $0.5 \mathrm{u} / \mathrm{gp}+$ emulsifying agent $0.2 \%$;

A-3, MTG $0.5 \mathrm{u} / \mathrm{gp}+$ emulsifying agent $0.5 \%$;

B-1, guar gum only $0.2 \%$;

B-2, MTG $0.5 \mathrm{u} / \mathrm{gp}+$ guar gum $0.2 \%$;

B-3, MTG $0.5 \mathrm{u} / \mathrm{gp}+$ guar gum $0.5 \%$;

C-1, wheat hydrolyzed agent only $0.2 \%$;

C-2, MTG $0.5 \mathrm{u} / \mathrm{gp}+$ wheat hydrolyzed agent $0.2 \%$;

C-3, MTG $0.5 \mathrm{u} / \mathrm{gp}+$ wheat hydrolyzed agent $0.5 \%$.

は示していないが，乳化剂 $0.5 \%$ では MTG 単独の $1.4 \mathrm{u} /$ gp で比容積が 3.48 に対して併用で 1.2 倍の 3.92 まで向上 した. 越智ら ${ }^{8)}$ はショ糖エステルを加えると分散性, 起泡 性が改良するとしており, ショ糖エステルは生地調整剤と してグルテンと特異的な結合性を有し，また，澱粉中のア ミロース，アミロペクチンとも複合体を形成するなどによ りケーキのしっとりした食感に寄与され MTG との併用に より Fig. 4 にみられるようなしっかりした形状のケーキ が得られた。これらのことからも， MTGと乳化剤との併 用により，小麦タンパク質との架橋形成による卵白生地 
（foam）の安定性が向上されたものと推察された。

一方, 増粘多糖類との併用では, 図には示していないが, MTG $1.4 \mathrm{u} / \mathrm{gp}$ と増粘多糖類 $0.2 \%$ 併用では比容積が MTG 単独より向上した. MTG $2.8 \mathrm{u} / \mathrm{gp}$ では乳化剂 $0.2 \%$ との併用では, 比容積 3.53 , 増粘多糖類 $0.2 \%$ との併用で は比容積 3.48 を示し, MTG 単独の場合よりも嵩比容はや や低い傾向を示した。

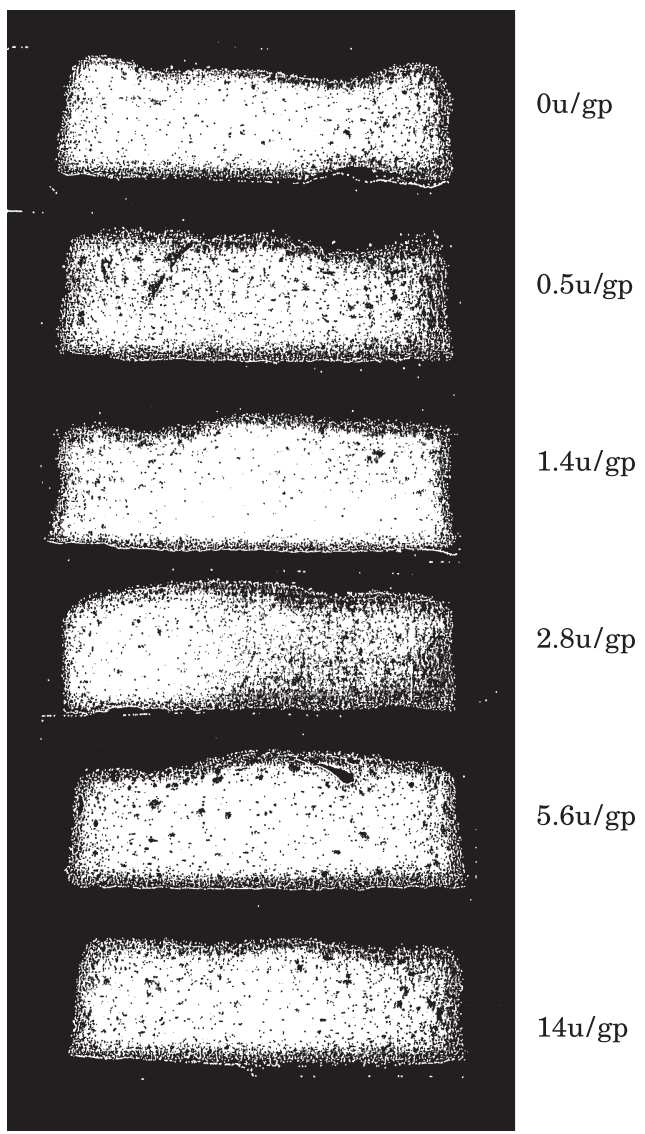

Fig. 4 Cross section of sponge cake with containing MTG 0 14 u/gp (flour basis)
小麦タンパク分解物との併用では，小麦タンパク質を添 加することとなり，タンパク質架橋重合化が進み，比容積 は小麦タンパク質の場合は，乳化剂，増粘多糖類の場合よ りあやや低下した。このことは，小麦タンパク質の増加が 適性以上に架橋重合化を促進させたためと推察された。

\section{3. 物性値と官能評価の関係}

破断試験によるケーキ物性は Fig. 5 からむ, MTG 0.5〜 $1.4 \mathrm{u} / \mathrm{gp}$ が最適添加量であった．破断強度および破断距離 あ向上し，弾力があり，内層が柔らかく，しっとりした食 感の傾向が得られた。さらに，Fig. 6 に MTG $0.5 \mathrm{u} / \mathrm{gp}$ 単 独に対して各改質材 $0.2 \%$ および $0.5 \%$ との併用系の結果 を示した。乳化剂との併用では破断距離は低下し，増粘多 糖類および小麦タンパク分解物との併用では破断距離の向 上がみられた。 MTG $1.4 \mathrm{u} / \mathrm{gp}$ の結果は図に示していない が，同様の結果を示した。官能評価による外観の色調，内 層の柔らかさ，しっとり感，保形性，総合評価の 5 項目を 評価した結果，Fig. 7 に示すように，MTGおよび乳化剂 との系では「柔らかさ」「しっとり感」が向上し，しなやか かな食感が得られ，MTG および増粘多糖類，小麦夕ンパ ク分解物では「保形性」が高く, クラスト部む厚くしっか りした形状であった。

増粘多糖類単独では破断強度の低下がやや見られ， MTG との併用による破断距離は向上して，ふんわりして やわらかい物性が得られたが，小麦タンパク分解物では増 粘多糖類と同様の傾向を示し，図には示していないが, MTG $1.4 \mathrm{u} / \mathrm{g}$ との併用により破断強度は 1.3 倍と高くな り，やや固めの食感となり好ましい物性は得られなかっ た.このようなことから MTGと改質材との併用によっ て，原料小麦粉中の小麦タンパク質のネットワーク構造が 形成されたあのと推察された。

\section{4. 保形性の評価}

MTG によるケーキ焼成後の保形性への影響は，焼成後 40 分放冷した断面の状態で評価した結果, MTG を添加し たものでは Fig. 4 のように，ケーキ全体に膨らみがみら

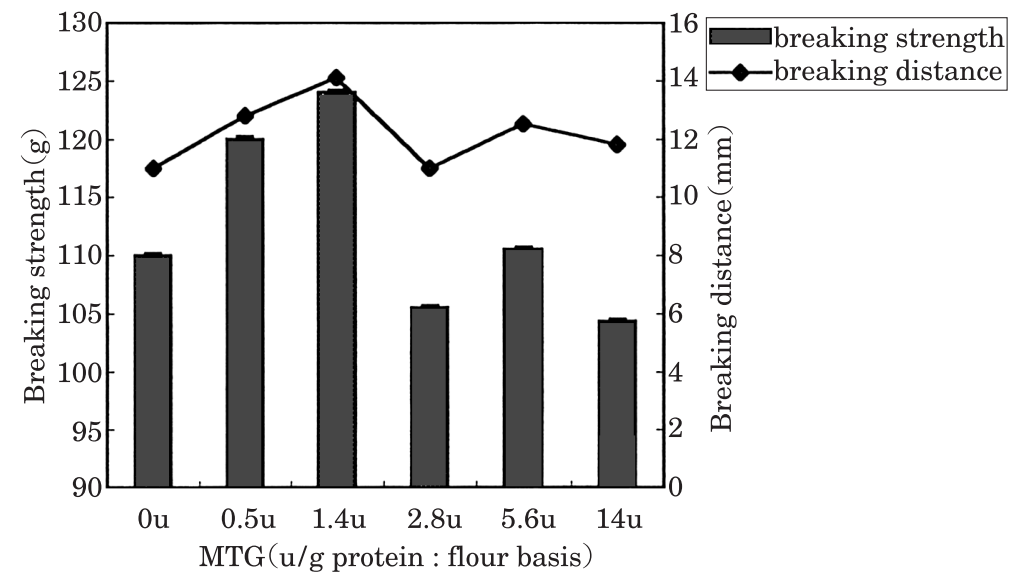

Fig. 5 Effect of MTG on the physical properties of sponge cake 
れ，上面中央部がやや高い形であり，凹み，皺など全くみ られなかった。無添加品は上面が僅かに凹みと, 特に, し わが多くみられ，冷却中の形状変化が大きかった． MTG $2.8 \mathrm{u} / \mathrm{gp}$ 以上では MTG 単独で用いると表皮部がやや硬く なる傾向を示したが，乳化剤および増粘多糖類 $0.2 \%$ との 併用においては，保形性のよいクラムが形成され，気泡が よくのびて, しっとりして柔らかい食感が得られた. 特に,
MTG $0.5 \mathrm{u} / \mathrm{gp}$ と乳化剂 $0.5 \%$ の併用では, 細かい気泡が 多くみられ，膨らみがよくなる傾向となった。

5. ケーキの水分

ケーキ焼成後, 室温まで冷えてから水分を測定した結果 Fig. 8 のように, MTG 1.4 14 u/gp 添加では, 微量である が水分值が高く保水効果がみられた。川染，山野6) らは焼成 によって薄い膜を形成して水分蒸発を防ぐとしている.

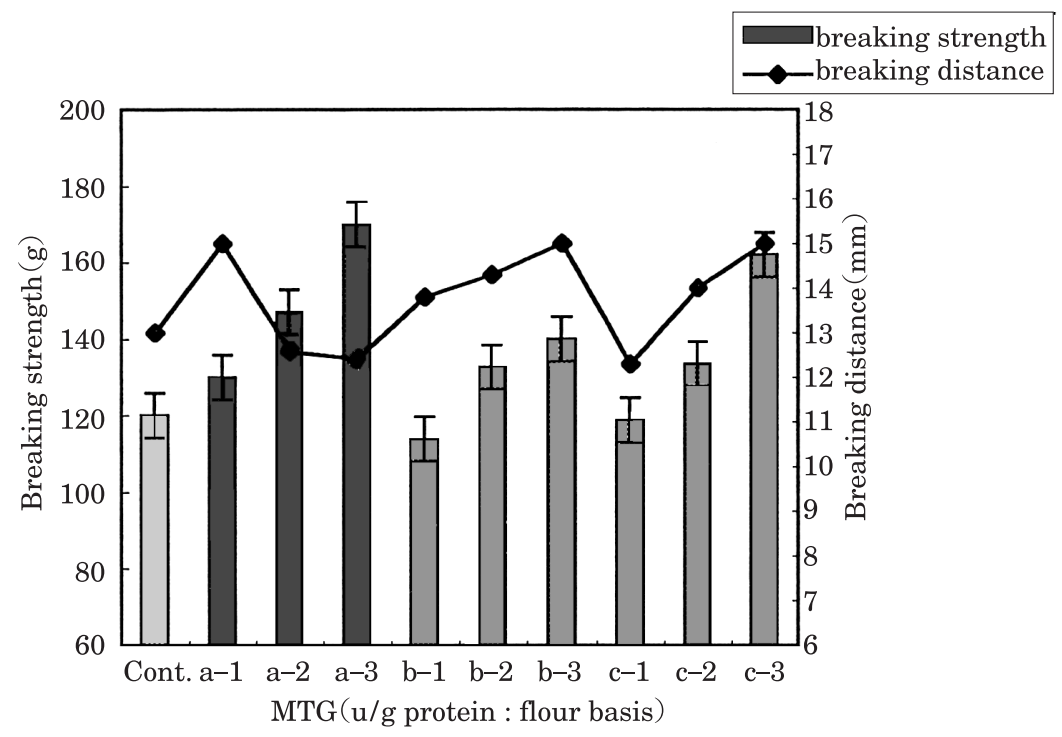

Fig. 6 Effect of MTG and improvement substances on sponge cake properties

Cont, MTG0.5 u/gp ;

a-1, emulsifying agent only $0.2 \%$;

a-2, MTG $0.5 \mathrm{u} / \mathrm{gp}+$ emulsifying agent $0.2 \%$;

a-3, MTG $0.5 \mathrm{u} / \mathrm{gp}+$ emulsifying agent $0.5 \%$;

b-1, guar gum only $0.2 \%$;

b-2, MTG $0.5 \mathrm{u} / \mathrm{gp}+$ guar gum $0.2 \%$;

b-3, MTG $0.5 \mathrm{u} / \mathrm{gp}+$ guar gum $0.5 \%$;

c-1, wheat hydrolyzed agent only $0.2 \%$;

c-2, MTG $0.5 \mathrm{u} / \mathrm{gp}+$ wheat hydrolyzed agent $0.2 \%$;

c-3, MTG $0.5 \mathrm{u} / \mathrm{gp}+$ wheat hydrolyzed agent $0.5 \%$.

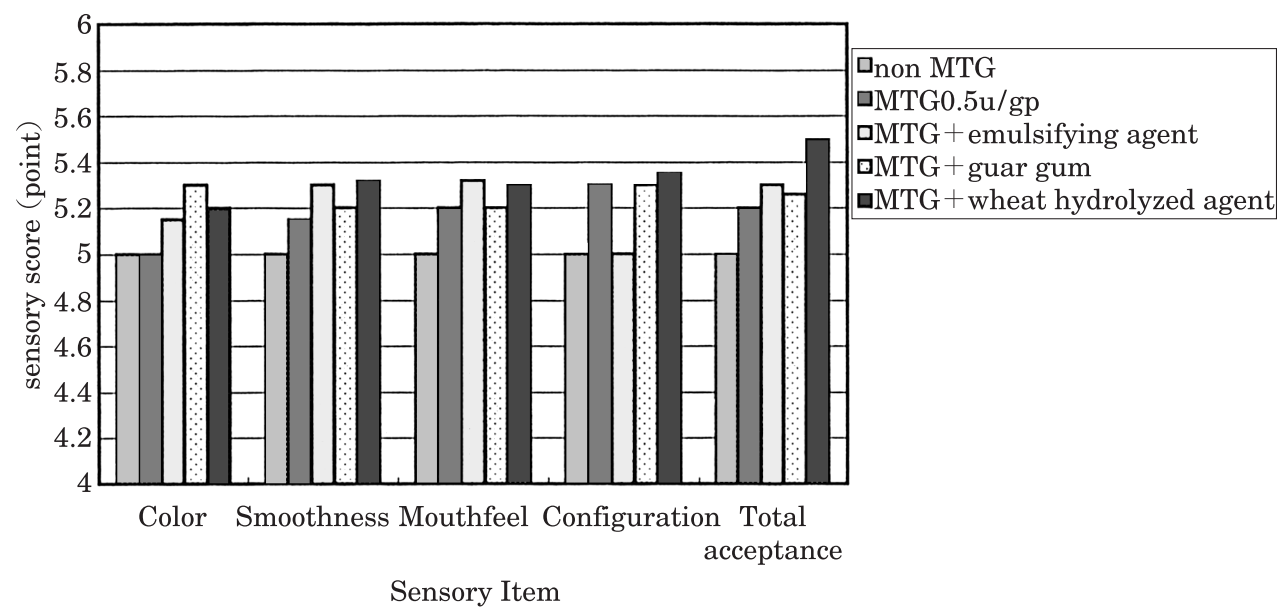

Fig. 7 Results of sensory evaluation of the sponge cake made with MTG and improvement substances (MTG : $0.5 \mathrm{u} / \mathrm{gp}$ and each $0.2 \%$ ) 


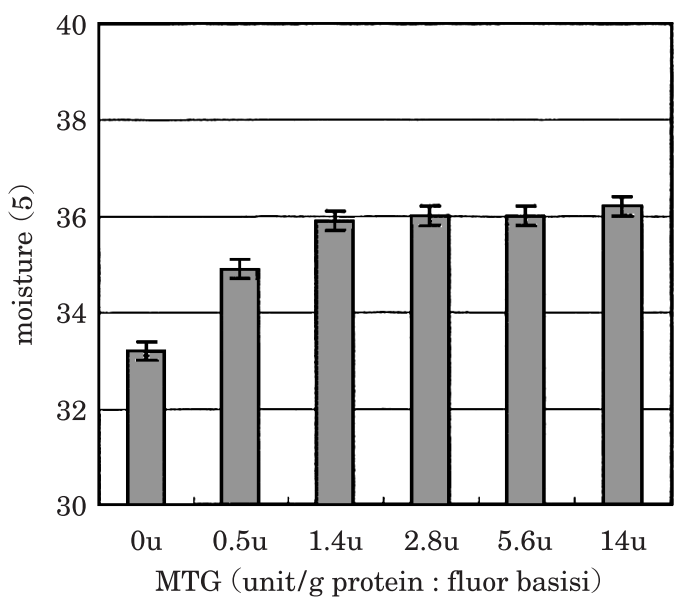

Fig. 8 Effect of MTG content at level of 0, 0.5, 1.4, 2.8, 5.6 and $14 \mathrm{u} / \mathrm{gp}$ on moisture of sponge cake

また, 藤井ら ${ }^{15)}$ は水の量が増すに従って膨化率は低下す るが, ケーキの硬さ, 弾力性, テクスチャ一等が良好にな ると報告している。麦タンパク質の架橋重合化により ケーキの表皮部がしっかりした構造に形成されることによ り水分の飛散が抑制され, 水分の保持量が MTG 添加でや や増大することによって, 力学物性が好ましい方向に改善 され官能評価でのしっとり感の向上に寄与したものと推定 された.

\section{6. 電気泳動パターンの変化}

MTG 添加によるケーキの電気泳動図を Fig. 9 に示した.

この結果, MTG 添加のケーキは, MTG $1.4 \mathrm{u} / \mathrm{gp}$ 以上の 酵素濃度で分子量 $4.3 \times 10^{4}$ のバンド（矢印 a）が僅かに濃 度が濃くなり, MTG $0.5 \mathrm{u} / \mathrm{gp}$ 以上では, 分子量 $3 \times 10^{4}$ の バンド (矢印 b) および $1.4 \times 10^{4}$ のバンド（矢印 c および d) の消失傾向が認められ, 重合化により小麦タンパク質のか なりの部分が不溶化したものと考えられる. そして, 比容 積の向上, 物性および官能評価などの変化からも MTGに よって小麦タンパク質の架橋が形成されることは明らか で, 架橋形成の結果比容積, 物性および官能評価の改善が なされたものと考えられた。

\section{要 約}

本研究では, タンパク質架橋重合化酵素であるトランス グルタミナーゼ (以下, MTG と略す) に着目して, スポン ジケーキの調製工程における有用性について検討した。 そ の結果, スポンジケーキの要件を満たすことが可能とな り，以下のような有用性をみることができた.

(1) MTGによりスポンジケーキの比容積の向上が図れた.

i ) MTG $0.5 \mathrm{u} / \mathrm{gp} \sim 5.6 \mathrm{u} / \mathrm{gp}$ 最も効果を発現された. 14 $\mathrm{u} / \mathrm{gp}$ では比容積の減少がみられた。 ii) MTG と他の改質 材 $0.5 \%$ との併用においては, 乳化剂, 増粘多糖類, 小麦夕 ンパク分解物の順に作用性が高く得られた。 iii） MTG 1.4

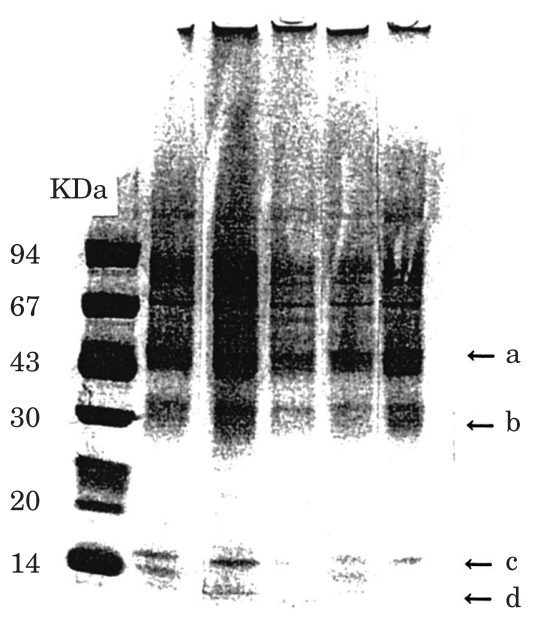

maker $0 \mathrm{u} 0.5 \mathrm{u} 1.4 \mathrm{u} 2.8 \mathrm{u} 5.6 \mathrm{u}$

Fig. 9 SDS-PAGE patterns of MTG sponge cake

$\mathrm{u} / \mathrm{gp}$ と乳化剂 $0.2 \%$ の併用において, MTG 単独に対し て, 約 1.2 倍の比容積を得た.

(2) MTGの添加により， スポンジケーキの上面の凹み や，皺むみられず形状の整ったスポンジケーキが得られ た. i ) MTG の最適添加量は $0.5 \sim 1.4 \mathrm{u} / \mathrm{gp}$ であった. ii） $2.8 \mathrm{u} / \mathrm{gp}$ 以上では表皮部がやや硬くなる傾向を示したが, 乳化剂, 増粘多糖類 $0.2 \%$ との併用において, 保形性のよ いクラムが形成され，気泡がよくのびて，しっとりして柔 らかい食感が得られた。

（3）破断試験による物性評価では，無添加に対して, MTG $1.4 \mathrm{u} / \mathrm{gp}$ 添加において破断強度が高くなり, 破断距 離ものびたことから, 弾力と柔らかさが向上する傾向が得 られるものと推定された。

(4) SDS-PAGEからも低分子グリアジン画分の減少が 認められた。これらのことから MTGによるスポンジケーキ の有用性および主な反応基質タンパク質などが示唆された.

最後に，本研究にあたり，官能検査にご協力いただいた 味の素(株) 商品開発センターの皆様に感謝いたします。

本論文の概要は, 平成 15 年 9 月, 東京農業大学での日本 食品科学工学会第 50 回大会において発表した.

\section{文献}

1）山木一史, 槙 賢治, 田中 彰, 田中常雄, 山木 携, 北海 道産小麦のスポンジケーキへの利用, 北海道立食品加工研 究センター報告, 2, 5-10 (1996).

2）川染節江，山野善正，バタースポンジケーキのテクスチャー に及ぼす砂糖含量の影響，家政誌，42，53-60（1991）。

3) Mizukoshi, M., Kawada, T. and Matsui, N., Model Studies of Cake Baking. V. Cake Shrinkage and Shear Modulus of Cake Batter During Baking. Cereal Chem., 62, 242-246 (1985).

4）川染節江, 山野善正, バタースポンジケーキのテクスチャー 
に及ぼすバター含量の影響, 家政誌, 37, 759-766 (1986).

5）前田智子, 浅川具美, 森田尚文, スポンジケーキの性状にお よぼすバ夕ー添加温度の影響, 家政誌, 50, 571-579 (1999).

6）川染節江，山野善正，バタースポンジケーキのテクス チャーに及ぼすバッター攪拌時間の影響, 家政誌, 38, 559566 (1987).

7）藤井淑子, 林ひろみ, 島田淳子, 吉松藤子, パウンドケーキ の品質に与える攪拌の影響. 家政誌, 30, 505-510 (1979).

8）越智知子, 総説 スポンジケーキの物性, 日調科誌, $22,84-$ 93 (1989).

9）渡辺豊子, 喜代吉夏子, 山田光江，ヶーキ焙焼過程における 生地温度履歴之製品への影響 (第 1 報)，日調科誌，25，293300 (1992)

10）渡辺豊子, 北尾敦子, 大喜多祥子, 山田光江, スポンジ・パ ウンドの焼成過程における生地温度履歴と製品への影響 （第 2 報），日調科誌，27，39-44（1994）.

11）渡辺豊子, 大喜多祥子, 福本夕ミ子, 山田光江, スポンジ ケーキ・パウンドケーキの焼成過程における生地温度履歴 之製品への影響 (第 4 報), 日調科誌，30，308-314（1997）.

12）井川佳子，スポンジケーキの焼成過程に及ぼす糖代替の影 響，食科工，45，357-363（1998）。

13）武田紀久子，小麦粉成分抢よび特性がスポンジケーキの膨 化に及ぼす影響 (第 4 報), 粉のエージングの影響, 家政誌,
43, 765-771 (1992).

14）山上ユリ子，スポンジケーキ・バッターの物性と調理，「食 品之物性」, 第 2 集, 山野善正, 松本幸雄編, ((株)食品資材 研究会), pp. 41-57 (1976).

15）藤井淑子, 島田淳子, 澱粉ヶーキの調製条件とその性状, 家 政誌，34，616-623（1983）。

16）武田紀久子，小麦粉成分扔よび特性がスポンジケーキの膨 化に及ぼす影響 (第 4 報), 粉のエージングの影響, 家政誌, 43, 765-771 (1992).

17) Folk, J.E. and Chung, S.I., Molecular and Catalytic Properties of Transglutaminases. Adv. Enzymol. 38, 110-171 (1973).

18) Laemmli, U.K., Cleavage of Structure Proteins during the Assembly the Head of Bacteriophage T4. Nature, 227, 680-685 (1970).

19) Kusunose, C., Kimura, T. and Fujii, T., Size Effects of Starch Granules on Porous Structure forwation of Sponge Cakes made from Potato Starch. 日調科誌，35, 10-18 (2002).

20）藤井恵子, 高橋貞幸, 木内留美子, 絹フィブロインと複合化 した米粉のスポンジケーキ調製とその特性，食科工， 47 , 363-368 (2000).

(平成 16 年 10 月 4 日受付，平成 17 年 3 月 2 日受理) 